\title{
Pengaruh Consumer Ethnocentrism Tendency, Persepsi Nilai dan Atribut Produk Terhadap Niat Beli dengan Sikap Konsumen sebagai Variabel Intervening
}

\author{
Atsnaul Chusna1, Sulis Riptiono \\ 1,2Sekolah Tinggi Ilmu Ekonomi Putra Bangsa \\ Email: asnaulc@gmail.com
}

\section{ARTICLE INFO}

Article History:

Received: March 3rd 2021

Accepted: April 1st 2021

Published: April 14th 2021

Keywords:

Ethnocentrism Tendency,

Persepsi Nilai, Atribut,

Sikap Konsumen, Niat

Beli

\begin{abstract}
Penelitian ini bertujuan untuk menguji pengaruh Consumer Ethnocentrism Tendency, Persepsi Nilai dan Atribut Produk terhadap Niat Beli dengan Sikap Konsumen sebagai Variabel Intervening. Metode pengambilan sampel yang digunakan adalah teknik Nonprobability sampling adalah teknik pengambilan sampel yang tidak diberi peluang/ kesempatan bagi setiap unsur atau anggota populasi untuk dipilih menjadi sampel.Pengumpulan data dilakukan dengan kuesioner, dengan menggunakan Skala Likert 4. Responden dalam penelitian ini mengambil sampel 100masyarakat di Kebumen yang memiliki niat untuk membeli batik Kebumen. Hipotesis diuji menggunakan program SPSS 24.00 for windows. Hasil penelitian ini menunjukan bahwa consumer ethnocentrism tendency, persepsi nilai dan atribut produk berpengaruh signifikan terhadap sikap konsumen, consumer ethnocentrism tendency berpengaruh signifikan terhadap niat beli namun persepsi nilai, atribut produk dan sikap konsumen tidak berpengaruh signifikan terhadap niat beli selain itu juga bahwa sikap konsumen tidak dapat memediasi CET, persepsi nilai dan atribut produk terhadap niat beli.Penelitian ini menggunakan metodeanalisis deskriptif dan statistik yang dilakukan uji validitas, ujireliabilitas, uji multikolinieritas, uji heteroskedestitas, uji normalitas,uji korelasi, koefisien determinasi, uji $\mathrm{t}$, dan analisis jalur.
\end{abstract}

\section{Pendahuluan}

Batik merupakan salah satu hal yang dilirik dalam industri fashion. Batik adalah salah satu warisan bangsa yang sudah terkenal di dunia setelah Perserikatan Bangsa Bangsa (PBB) membawahi masalah kebudayaan, UNESCO telah mengakui batik pada tanggal 2 oktober 2009 sebagai warisan kemanusiaan untuk budaya lisan dan nonbendawi (Masterpieces of the oral land and the intangible hertage of humality). Batik merupakan salah satu bentuk karya seni bangsa Indonesia yang dikagumi oleh dunia sekaligus mempunyai nilai tinggi. Batik dikatakan sebagai hasil budaya yang bernilai tinggi karena proses pembuatan batik dilakukan secara tradisional serta turun temurun.

Di Indonesia, batik memiliki berbagai macam motif dan corak yang tentunya sangat 
menarik untuk di lirik. Netralnews.com, presiden jokowi melalui akun twiter resminya mengatakan bahwa batik merupakan salah satu industri kreatif yang dapat menggerakan ekonomi nasional. Beliau juga mengajak masyarakat untuk ikut mengembangkan batik yang sudah diakui oleh dunia. Saat ini batik bukan lagi sebagai komoditas yang hanya digunakan oleh kalangan orang tua saja. Batik mulai memasuki pasar di kalangan remaja dan merajai komoditas fashion. Model dan motif batik semakin berkembang dan mengikut trend. Batik sudah tidak di anggap hal yang kuno lagi, para remaja sudah tidak canggung lagi untuk memakainyaa dalam berbagai aktivitas mereka dengan hal tersebut dimana eksistensi batik semakin hari menunjukan jati dirinya, tidak terkecuali di Kebumen.

Kebumen adalah salah satu kota yang kecil yang terdapat daerah pembuatan batik Kebumen salah satunya yaitu di desa gemeksekti. Gemeksekti adalah desa yang sudah diresmikan sebagai kampung batik oleh bapak bupati Kebumen Yazid Mahfudz yang di tandai adanya pembangunan gapura pada tanggal 10 maret 2020 oleh pemerintah Kabupaten Kebumen. Pembangunan gapura tersebut sebagai pintu masuk kampung batik dan di harapkan menjadi sarana promosi dan publikasi akan Keberadaan Kampung Batik Di Desa Gemeksekti. Desa Gemeksekti memang layak menyanding predikat sebagai kampung batik pasalnya desa ini merupakan salah satu sentra kerajinan batik di Kebumen dengan jumlah perajin batik yang mencapai ratusan orang. Di desa ini terdapat dua dukuh yang menjadi sentra perajin batik yakni Tanuraksan dan Watubarut. Namun saat ini yang paling banyak memproduksi batik berada di Tanuraksan.

Batik Kebumen berbeda dengan keberadaan batik-batik di daerah lain yang masing masing memiliki latar dan pengaruh dari berbagai unsur, sehingga batik dapat berkembang sebagai sebuah simbol budaya, adat istiadat dan spiritual. Batik Kebumen lebih berkembang sebagai murni seni batik yang menekankan pada nilai artistik bukan pada nilai filosofi yang bermakna nilai moral dan dan harapanharapan. Sehingga justru menunjukan keunikan sendiri. Batik Kebumen yang berorientasi pada alam (ekologis) menggambarkan masyarakat Kebumen yang bersahaja dan sangat menghormati kehidupan yang di tawarkan oleh alam (ekologis).

Di Kebumen batik semakin di lestarikan keberadaannya. Hal ini di perkuat adanya peraturan pemerintah baik untuk instansi negeri maupun swasta untuk menggunakan pakaian batik lokal pada hari kamis (Lintas Kebumen.2014), selain itu juga (ini Kebumen.net 2019) berdasarkan Peraturan Bupati (perbup) nomor 35 tahun 2017 tentang Pakaian Adat Khas Kabupaten Kebumen adanya pemakaian kain batik Kebumen dengan ketentuan pakaian adat untuk laki-laki pada bagian lancangan bebed panjen menggunakan kain batik Kebumen motif jagatan latar putih bahan katun sedangkan untuk perempuan menggunakan kain batik motif jagatan latar putih dengan wiron mataram dengan bahan katun dan untuk kalangan pelajar pemerintah juga mewajibkan untuk pengganti seragam identitas sekolah menggunakan seragam batik lokal (suara merdeka.com). melalui program tersebut permintaan batik sangat diminati oleh berbagai kalangan di Kebumen maupun di luar Kebumen. 
Tabel 1. Observasi Terhadap Purchase Intention Pada Batik Kebumen

\begin{tabular}{lc}
\hline \multicolumn{1}{c}{ Pembelian } & Jumlah \\
\hline Pernah membeli & 23 \\
Belum pernah membeli & 12 \\
Jumlah & 35 \\
\hline Sumber: survey masyarakat Kabupaten Kebumen (2020)
\end{tabular}

Tabel 2. Faktor Yang Mempengaruhi Purchase Intention Pada Batik Kebumen

\begin{tabular}{lcc}
\hline Niat Beli Batik Kebumen & Jumlah & Prosentase \\
\hline Consumer Ethnocentrism Tendency & 25 & 58,14 \\
Persepsi Nilai & 10 & 23,25 \\
Atribut Produk & 8 & 18,60 \\
Total & $\mathbf{4 3}$ & $\mathbf{1 0 0}$ \\
Sumber: survey masyarakat Kabupaten Kebumen (2021)
\end{tabular}

Berdasarkan data di atas, dapat dilihat bahwa niat beli konsumen terhadap batik Kebumen faktor terbesar karena adanya kecintaan terhadap produk lokal, yang menganggap bahwa orang Kebumen malu jika tidak memiliki batik produksi daerah tempat tinggalnya hal tersebut merupakan adanya faktor dari consumer etnocentrismtendecy sebesar 25 responden. Faktor kedua yaitu adanya persepsi penilaian konsumen terhadap batik (perceive value) sebesar 10 responden dimana adanya anggapan bahwa batik Kebumen memiliki kualitas yang tidak kalah baik dengan produksi batik dari kota lain, kualitas batik Kebumen sebanding dengan harga yang di tawarkan. Faktor niat beli batik Kebumen yang terakhir adanya pengaruh atribut produk batik Kebumen sebesar 8 responden, dimana masyarakat Kebumen menganggap bahwa adanya desain batik Kebumen yang menarikdan adanya merek yang sudah melekat di benak konsumen yaitu yang terdapat didesa gemeksekti yang merupakan produksi batik Kebumen, dari ketiga faktor tersebut sehingga mempengaruhi adanya sikap konsumen (consumer attitude) terhadap niat beli (purchase intention) batik Kebumen.

Niat di asumsikan sebagai faktor emosional yang mempengaruhi perilaku. Hal tersebut merupakan indikasi orang berkehendak untuk melakukan usaha mereka yang di rencanakan dalam melakukan perilaku. Semakin kuat niat untuk berperilaku menjadi ekspresi dalam berperilaku, jika perilaku tersebut dibawah kontrol kehendak yaitu jika orang tersebut dapat memutusakan melakukan atau tidak melakukan perilaku tersebut (Ajzen, 1991). Ketika konsumen telah memiliki niat untuk membeli sebuah produk, hal tersebut merupakan suatu bentuk komitmen yang positif terhadap suatu produk (Riptiono, 2018).

Studi yang telah dilakukan bahwa ada beberapa hal yang mempengaruhi niat beli batik Kebumen yaitu adanya pengaruh sikap konsumen. Menurut Robbins (2006) sikap konsumen adalah pernyataan-pernyataan atau penilaian evaluasi berkaitan dengan obyek atau suatu peristiwa. Batik Kebumen memiliki berbagai varian model yang sangat bermacam-macam seperti jagatan Kebumen, gringsing, parang rusa, sirkit, sehingga konsumen dalam melakukan penilaian suka atau tidak nya produk yang di tawarkan dapat dilakukan dengan mudah karena begitu banyak varian motif atau desain yang di tawarkan dengan harga yang sesuai. Hal tersebut di dukung adanya pendapat menurut Schiffman dan Kanuk (dalam Suryani, 2008) menyatakan bahwa sikap merupakan ekspresi perasaan yang berasal dari 
dalam diri individu yang mencerminkan apakah seseorang suka atau tidak, dan setuju atau tidak setuju terhadap suatu objek.

Sangat penting bagi pengusaha untuk membuat batik menjadi produk yang melekat dengan konsumen, sehingga konsumen yang memilki sikap ethnosentrism akan lebih memilih produk dalam negeri di bandingkan dengan produk luar. Namun karena perilaku masyarakat Indonesia yang terbuka ini dapat mengancam produk dalam negeri,terlebih jika konsumen Indonesia sendiri lebih memilih merek dari negara lain, seperti dalam hasil penelitan yang dilakuakan oleh purwanto (2014) bahwa konsumen Indonesia cenderung memilki tingkat etnosentris konsumen yang rendah. Hal ini menjadi sebuah permasalahan bagi produsen lokal untuk merubah persepsi tersebut dan menumbuhkan rasa cinta terhadap produk lokal.

Perceived value juga memiliki pengaruh penting terhadap niat beli konsumen. Menurut (Ariifin et al., 2013) Perceived value merupakan konsumen secara keseluruhan akan faedah dari suatu produk berdasarkan persepsi mengenai apa yang telah mereka berikan. Jadi jika konsumen memiliki persepsi yang tinggi terhadap suatu produk maka semakin tinggi pula niat beli konsumen, yang berarti persepsi nilai memiliki pengaruh positif terhadap niat beli (Hansudoh 2012), sehingga konsumen yang memiliki ethnocentrism yang tinggi dan memiliki persepsi nilai yang tinggi terhadap suatu produk menjadi sebuah pertimbangan bagi konsumen untuk meningkatkan niat beli.Pengusaha batik atau para pengrajin batik Kebumen dalam mengenalkan batik Kebumen dengan berbagai cara yang sudah di lakukan.

Contoh langkah yang sudah di ambil adalah dengan mengadakan fashion show di berbagai daerah dan mengikuti bazar, dengan langkah-langkah tersebut batik Kebumen dapat dikenal di berbagai daerah terutama daerah di Kabupaten Kebumen. Hal tersebut dapat memunculkan persepsi penilaian terhadap batik Kebumen, bahwa batik Kebumen juga tidak kalah saing dengan batik yang ada di kota-kota besar seperti yogyakarta, solo, semarang dan lain-lain. Konsumen yang awalnya mengangap batik Kebumen tidak menarik, dengan adanya berbagai langkah pemerintah dalam memperkenalkan produk batik Kebumen di harapkan dapat mengubah persepsi tersebut dengan menjadikan batik Kebumen menjadi salah satu produk unggulan yang harus di (lestarikan) gunakan dalam aktifitas sehari-hari sehingga batik Kebumen akan semakin di kenal oleh daerah luar.

Faktor lain yang mempengaruhi niat beli konsumen yaitu atribut produk. Menurut Peter dan Olson (2010:392), atribut produk adalah rangsangan utama yang mempengaruhi perasaan, pikiran dan perilaku konsumen dalam menentukan keputusan pembelian. Atribut produk sering sebagai sesuatu yang dinilai konsumen sebagai faktor yang menentukan relevansi dirinya dengan produk. Sehingga bertanya kepada konsumen atribut mana yang dianggap penting merupakan cara yang tepat untuk mengetahui pertimbangan keputusan pembelian atau penggunaan suatu produk oleh konsumen (Suhardi 2008). Konsumen dalam melihat sebuah produk sebagai sekumpulan atribut (bundle of atributes) dengan kemampuan yang berbeda-beda untuk setiap produk. Konsumen dalam membedakan satu produk dengan produk lainnya melalui atribut ini, sehingga sering muncul pasar untuk suatu produk dapat begitu tersegmen mengacu pada atribut yang menonjol untuk kelompok konsumen yang berbeda. Beitupula adanya atribut seperti merek,corak, model pada batik Kebumen yang sudah mulai melekat di benak konsumen. 


\section{Kajian Teori dan Telaah Literatur}

\section{Purchase Intention}

Niat juga di asumsikan sebagai faktor emosional yang mempengaruhi perilaku, dengan begitu hal tersebut merupakan indikasi orang berkehendak untuk melakukan usaha mereka yang di rencanakan dalam melakukan perilaku. Pernyataan tersebut didukung adanya penelitian terhadap niat beli konsumen, model Theory of Reason Action(Fishbein dan Azjen, 1975) merupakan pendekatan yang paling berpengaruh untuk menjelaskan anteseden dari perilaku konsumen. Dalam pandangan TRA, niat dapat mempengaruhi perilaku seseorang, sedangkan faktor-faktor yang mempengaruhi niat adalah sikap dan norma subyektif (Fishbein dan Azjein, 1991). Bandura (1986) mengemukakan bahwa niat merupakan suatu kebulatan tekad untuk melakukan aktivitas tertentu atau menghasilkan suatu keadaan tertentu dimasa depan. Niat berperilaku (Fishbein \& Azjen, 1991) merupakan komponen dalam diri individu yang mengacu pada keinginan untuk melakukan tingkah laku tertentu. Menurut Teori Utilitas, kemungkinan niat beli akan meningkat, ketika konsumen memperoleh lebih banyak manfaat daripada yang mereka bayarkan untuk sebuah produk. Niat beli terbentuk dari beberapa faktor psikologis yaitu motivasi, persepsi terhadap rangsangan, kepercayaan dan sikap (Sutojo dan Kleinsteuber, 2002.65) . Jadi niat beli adalah suatu tingkatan akhir dalam minat beli berupa keyakinan sebelum keputusan pembelian diambil.

\section{Sikap Konsumen}

Keyakinan dan pilihan konsumen atas suatu merek merupakan sikap konsumen. Dalam banyak hal, sikap terhadap merek tertentu akan mempengaruhi apakah konsumen jadi membeli atau tidak. Disebutkan bahwa sikap merupakan konsep yang paling khusus dan sangat dibutuhkan dalam psikologis sosial kontemporer, sehingga dapat dikatakan bahwa sikap merupakan salah satu konsep yang terpenting oleh pemasar untuk memahami konsumen. Definisi awal sikap yang dikemukakan oleh Thurstone (dalam Azwar, 1988), dia melihat sikap sebagai salah satu konsep yang cukup sederhana, yaitu jumlah pengaruh yang dimiliki seseorang atas atau menentang suatu objek. Sedangkan definisi sikap yang dikemukakan oleh Allport makna sikap yaitu mempelajari kecenderungan memberikan tanggapan terhadap suatu objek baik disenangi ataupun tidak disenangi secara konsisten. Hal tersebut di dukung adanya pendapat menurut Schiffman dan Kanuk (dalam Suryani, 2008) menyatakan bahwa sikap merupakan ekspresi perasaan yang berasal dari dalam diri individu yang mencerminkan apakah seseorang suka atau tidak, dan setuju atau tidak setuju terhadap suatu objek.

Namun saat ini sebagian periset setuju dengan konsep sederhana terkait sikap yang di ajukan oleh Thurstone dan Fishbein ialah yang paling bermanfaat. Artinya sikap mewakili sebuah perasaan senang atau tidak senang konsumen terhadap objek yang di pertanyakan. Kepercayaan (kognisi) dan keinginan untuk bertindak (conation) di lihat memiliki hubungan dengan sikap, namun merupakan konsep kognitif yang terpisah bukan bagian dari sikapnitu sendiri.

\section{Consumer Ethnocentrism Tendency}

Dari konsep etimologi etnosentris, Sumner (1906) dalam Chang dan Cheng (2011) mendefinisikan etnosentrisme adalah pandangan terhadap sesuatu dimana kelompok 
sendiri sebagai pusat dari segala sesuatu dan semua yang lain diukur dan dipandang dengan rujukan kelompoknya, setiap kelompok memupuk kebanggaan dan kesombongannya sendiri, membanggakan dirinya superior, mengagungkan Tuhan mereka sendiri dan melihat dengan memandang rendah kelompok luar yang lainnya. Dari konsep dasar ini, dapat dikatakan etnosentrisme adalah kecenderungan individu dalam melihat kelompok mereka lebih baik, lebih unggul, lebih superior dibandingkan kelompok lainnya.

Etnosentrism konsumen didefinisikan sebagai preferensi konsumen terhadap produk yang diproduksi di dalam negeri dan menolak produk impor (Sharma et al.1995). Sehingga dapat dikatakan bahwa Etnosentrisme dapat diinterpretasikan bahwa membeli produk impor adalah sesuatu yang salah, tidak patriotik, dan mengganggu perekonomian (Shimp danSharma, 1987) (dalam Ida, 2013). Hal bahwa Konsumen yang memiliki kecenderungan ethnocentrism akan merasa takut untuk membeli produk dari negara lain, karena ada faktor moral dan personal prejudice yang akan di letakkan oleh kelompok masyarakatnya.

Penelitian menunjukkan bahwa konsumen di negara berkembang akan cenderung memandang produk lokal memiliki kualitas yang lebih tinggi daripada produk yang diimpor (misalnya, Damanpour, 1993; Elliot dan Cameron, 1994). Temuan dari penelitian ini juga menunjukkan bahwa sensitivitas budaya memiliki dampak yang positif pada penilaian produk impor.

\section{Perceive Value}

Menurut Zeithaml (1988) dalam aubrey et al mengungkapkan perceived value adalah: "perceived value is the consumer's overall assessment of the utility of a product based on perception of what is received and what is given ", kutipan diatas mempunyai arti bahwa perceived value adalah keseluruhan penilaian konsumen terhadap kegunaan suatu produk atas apa yang diterima dan yang diberikan oleh produk itu. Rahab, et al (2015) dalam Payne dan holt (2001) mengungkapkan perceived value adalah trade off antara manfaat yang dipersepsikan (atau konsekuensi positif dan negatif). Menurut perspektif kualitas, value adalah perbedaan antara uang yang dibayarkan untuk suatu produk dan kualitas produk yang didapatkan. Ketika semakin sedikit uang yang dibayarkan untuk barang dengan kualitas tinggi, maka nilai positif yang dirasakan dapat terbentuk. Manfaat yang didapatkan menunjukan nilai yang dirasakan adalah evaluasi keseluruhan dari utilitas manfaat yang dirasakan dan pengorbanan yang dirasakan (Zeithaml, 1988).

Mengingat bahwa pada dasarnya terdiri dari kumpulan fitur yang berkaitan dengan persepsi konsumen terhadap nilai produk, perceived value dapat didorong melalui efek kata positif dari mulut ke mulut dan padagilirannya dapat meningkatkan purchase intention. Gounaris, Tzempelikos, dan Chatipanagiotou (2007) melaporkan bahwa niat membeli konsumen dan persepsi nilai berhubungan positif. Salah satu ukuran yang diajukan untuk mengevaluasi customer value adalah perceived value (perval) (Tjiptono, 2015:100).Dengan demikian, kehilangan purchase intention dapat terjadi karena tingkat perceived value yang rendah.

\section{Product Attribut}

Adanya atribut pada sebuah produk memiliki peran yang penting, karena atribut produk menjadi salah satu faktor yang menjadi pertimbangan konsumen dalam memilih suatu produk tersebut dan setiap produk pasti memiliki karakteristik fisik yang membedakan 
dengan produk pesaing yang di sebut atribut produk, atribut produk adalah segala hal yang melekat pada produk atau menjadi bagian dari produk itu sendiri (Dimyati 2012). Kotler\&Amstrong (2012:254) mengatakan bahawa atribut produk merupakan karakteristik dari produk atau jasa yang menghasilkan kemampuan untuk memuaskan yang dinyatakan atau tersirat pada kebutuhan konsumen. Dapat dikatakan bahwa atribut produk adalah suatu komponen yang merupakan sifat-sifat produk yang menjamin agar produk tersebut dapat memenuhi kebutuhan dan keinginan yang diterapkan oleh pembeli.

Atribut produk menurut Fandy Tjiptono (2001) adalah "Unsur-unsur produk yang dipandang penting oleh pelanggan dan dijadikan sebagai dasar pengambilan keputusan". Atribut produk meliputi merek, kemasan, jaminan (garansi), pelayanan, dan sebagainya. Menurut Kotler (2008) “Atribut produk adalah karakteristik yang melengkapi fungsi dasar produk".

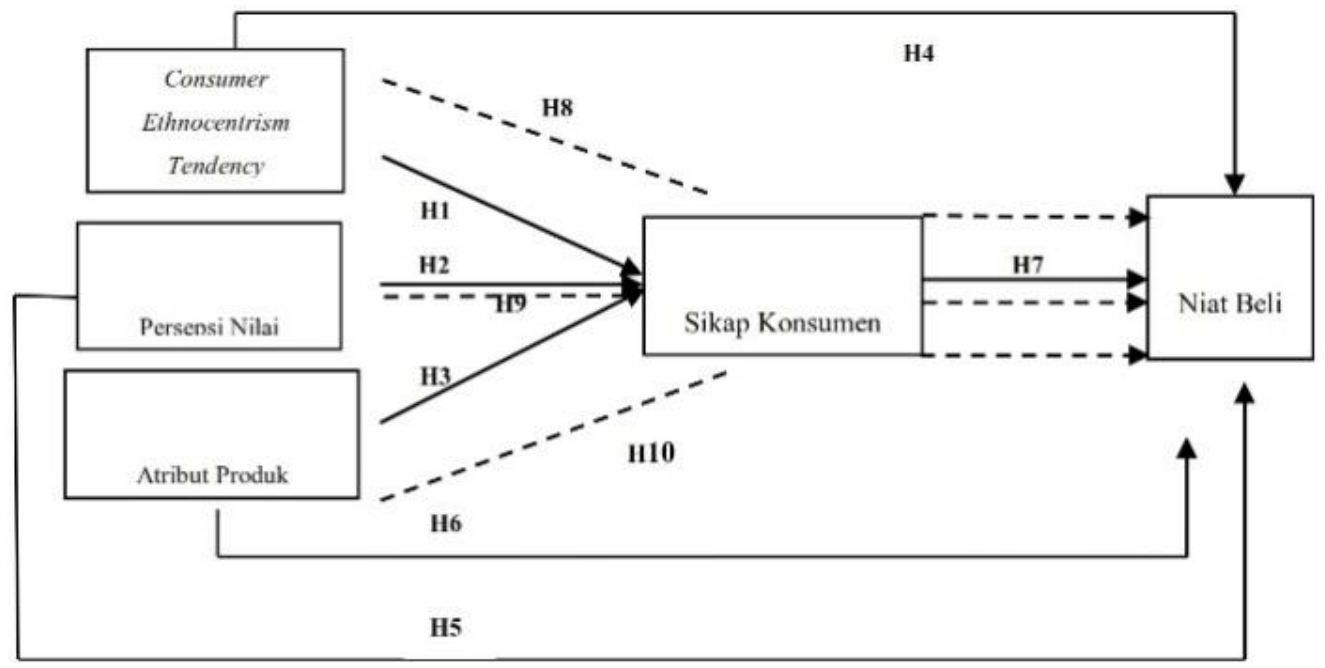

Gambar 1. Model Penelitian

$\mathbf{H}_{1}$ : Consumer ethnocentrism tendencyberpengaruh positif terhadap sikap konsumen.

$\mathbf{H}_{2}$ : Persepsi nilai berpengaruh positif terhadap sikap konsumen.

$\mathbf{H}_{3}$ : Atribut produk berpengaruh positif terhadap sikap konsumen.

$\mathbf{H}_{4}$ : Consumer ethnocentrism tendencyberpengaruh positif terhadap niat beli.

$\mathbf{H}_{5}$ : Persepsi nilai berpengaruh positif terhadap niat beli.

$\mathbf{H}_{6}$ : Atribut produk berpengaruh positif terhadap niat beli.

$\mathbf{H}_{7}$ : Sikap konsumen berpengaruh positif terhadap niat beli.

$\mathbf{H}_{\mathbf{8}}$ : Consumer ethnocentrism tendencyberpengaruh positif terhadap niat beli.

$\mathbf{H}_{9}$ : Persepsi nilai berpengaruh positif terhadap niat beli.

$\mathbf{H}_{10}$ :Atribut produk berpengaruh positif terhadap niat beli. 


\section{Metode Penelitian}

\section{Objek dan Subjek}

Objek dalam penelitian yang digunakan ini adalah consumer ethnocentrism tendency, persepsi nilai, atribut produk sebagai variabel bebas (independent) terhadap niat beli variabel terikat (dependent).melalui sikap konsumen sebagai variabel intervening pada batik Kebumen. Subjek dalam penelitian ini adalah masyarakat Kabupaten Kebumen yang belum pernah membeli batik Kebumen. Sugiyono (2010) mengemukakan bahwa sampel adalah bagian dari jumlah dan karakteristik yang dimiliki oleh populasi tersebut. Bila populasi besar, dan penelitian tidak mungkin mempelajari semua yang ada pada populasi, misalnya keterbatasan dana, tenaga, dan waktu, maka penelitian dapat menggunakan sampel yang diambil dari populasi itu. Sampel pada penelitian ini adalah masyarakat Kabupaten Kebumen yang berumur minimal 17 tahun dan niat membeli batik Kebumen.

\section{Populasi dan Sampel}

Populasi dalam penelitian adalah masyarakat di Kabupaten Kebumen yang belum pernah membeli batik Kebumen tetapi memiliki keniatan untuk membeli batik Kebumen. Teknik pengambilan sampel yang digunakan dalam penelitian ini adalah nonprobability sampling. Nonprobability sampling adalah teknik pengambilan sampel yang tidak memberikan kesempatan atau peluang yang sama bagi setiap unsur atau anggota dari populasi untuk dipilih menjadi sampel (Sugiyono, 2010).

Teknik nonprobability sampling yang digunakan dalam penelitian ini adalah purposive sampling yaitu teknik penentuan sampel dengan pertimbangan tertentu (Sugiyono, 2010).

\section{Analisis Kuantitatif}

Analisis kuantitatif adalah metode analisis data dengan menggunakan angka-angka yang diperoleh dari hasil jawaban reponden pada kuesioner. Dalam pengolahan data, peneliti mempergunakan alat bantu yang berupa aplikasi komputer yaitu SPSS for Windows versi 24.0

\section{Hasil dan Pembahasan}

\section{Uji Validitas dan Reliabilitas}

Tabel 3. Hasil Uji Validitas

\begin{tabular}{llll}
\hline Variabel & Butir & Signifikan & Status \\
\hline Consumer & 7 & Signifikan & Valid \\
Ethnocentrism & & & \\
Tendency & & & \\
Persepsi Nilai & 5 & Signifikan & Valid \\
Atribut Produk & 3 & Signifikan & Valid \\
Sikap & 3 & Signifikan & Valid \\
Konsumen & & & \\
Niat Beli & 4 & Signifikan & Valid \\
Sumber: Data Primer diolah, 2021 &
\end{tabular}


Hasil uji validitas seluruh pernyataan yang digunakan dalam variable Consumer Ethnocentrism Tendency (CET), persepsi nilai, atribut produk, sikap konsumen dan niat beli seluruhnya valid.

Tabel 4. Hasil Uji Reliabilitas

\begin{tabular}{lccc}
\hline \multicolumn{1}{c}{ Variabel } & $\begin{array}{c}\text { Nilai } \\
\text { Cronbach } \\
\text { Alpha } \\
\text { Minimum }\end{array}$ & $\begin{array}{c}\text { Cronbach's } \\
\text { Alpha }\end{array}$ & Keterangan \\
\hline $\begin{array}{l}\text { Consumer } \\
\text { Ethnocentrism }\end{array}$ & 0,60 & 0,778 & Reliabel \\
$\begin{array}{l}\text { Tendency } \\
\text { (X1) }\end{array}$ & & & \\
$\begin{array}{l}\text { Persepsi Nilai (X2) } \\
\text { Atribut Produk (X3) }\end{array}$ & 0,60 & 0,902 & Reliabel \\
$\begin{array}{l}\text { Sikap Konsumen } \\
\text { (Y1) }\end{array}$ & 0,60 & 0,694 & Reliabel \\
Niat Beli (Y2) & 0,60 & 0,821 & Reliabel \\
Sumber: Data Primer diolah, 2021 & 0,759 & Reliabel \\
\hline
\end{tabular}

Hasil Uji Reliabilitas menunjukkan bahwa seluruh instrumen yang digunakan dalam penelitian ini, memiliki nilai cronbach's alpha lebih dari 0,60. Hasil tersebut menunjukkan bahwa semua instrumen dalam penelitian ini dinyatakan reliabel.

\section{Uji Multikolinearitas}

Tabel 5. Uji Multikolinearitas Sub Stuktural I

\begin{tabular}{lcc}
\hline \multirow{2}{*}{ Variabel } & \multicolumn{2}{c}{ Collinearity Statistics } \\
\cline { 2 - 3 } & Tolerance & VIF \\
\hline CET & 0,524 & 1,908 \\
Persepsi Nilai & 0,514 & 1,946 \\
Atribut Produk & 0,742 & 1,348 \\
\hline
\end{tabular}

Sumber: Data Primer diolah, 2021

Tabel 6. Uji Multikolinearitas Sub Stuktural I

\begin{tabular}{lcc}
\hline \multirow{2}{*}{ Variabel } & \multicolumn{2}{c}{ Collinearity Statistics } \\
\cline { 2 - 3 } & Tolerance & VIF \\
\hline CET & 0,524 & 1,908 \\
Persepsi Nilai & 0,514 & 1,946 \\
Atribut Produk & 0,742 & 1,348 \\
Sikap Konsumen & 0,495 & 2,020 \\
\hline Sumber: Data Primer diolah, 2021
\end{tabular}

Berdasarkan Tabel coefficients di atas dapat dijelaskan bahwa pada bagian collinerity statistic menunjukan angka VIF dibawah 10 dan tolerance di atas 0,1 , karena itu model regresi ini tidak terdapat multikolinieritas, sehingga model regresi pada penelitian ini dapat dipakai. 


\section{Uji Heteroskedastisitas}

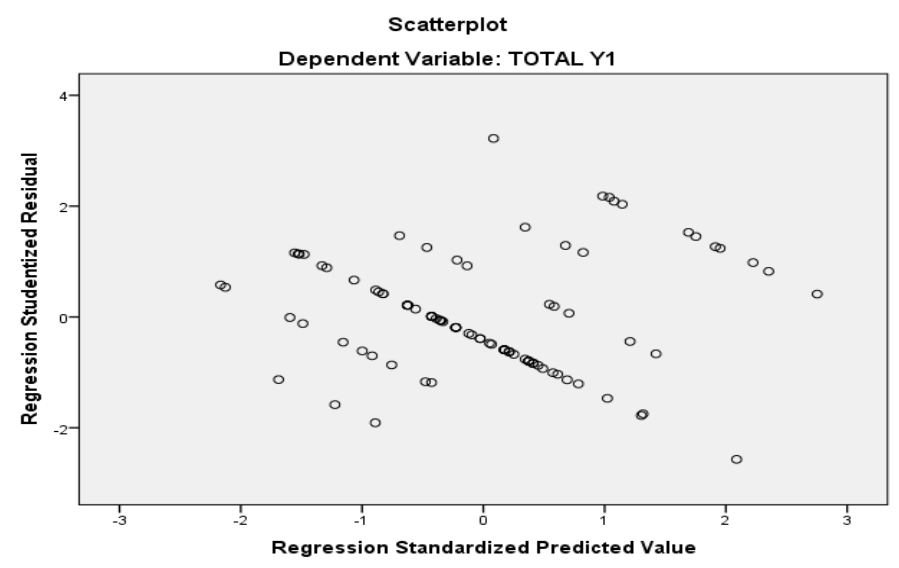

Sumber: Data Primer diolah, 2021

Gambar 2. Uji Heteroskedastisitas Sub Stuktural I

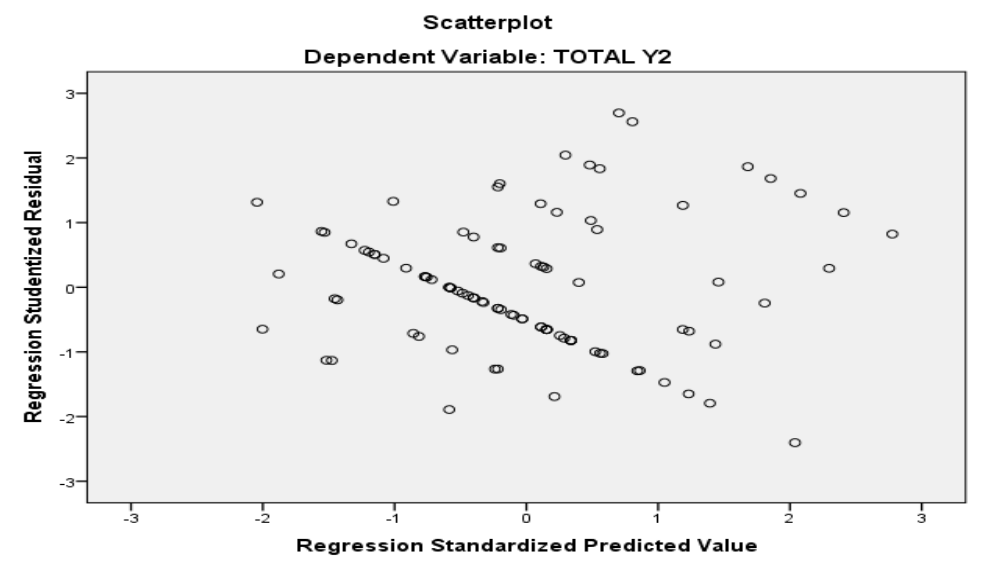

Sumber: Data Primer diolah, 2021

\section{Gambar 3. Uji Heteroskedastisitas Sub Stuktural II}

Berdasarkan gambar 2 dan 3, menunjukkan bahwa pada hasil uji heteroskedastisitas substruktural 2 dan 3 datanya menyebar dan tidak membentuk pola tertentu. Sehingga dapat disimpulkan bahwa semua variabel penelitian tersebut terbebas dari gejala heterokedastisitas. 


\section{Uji Normalitas}

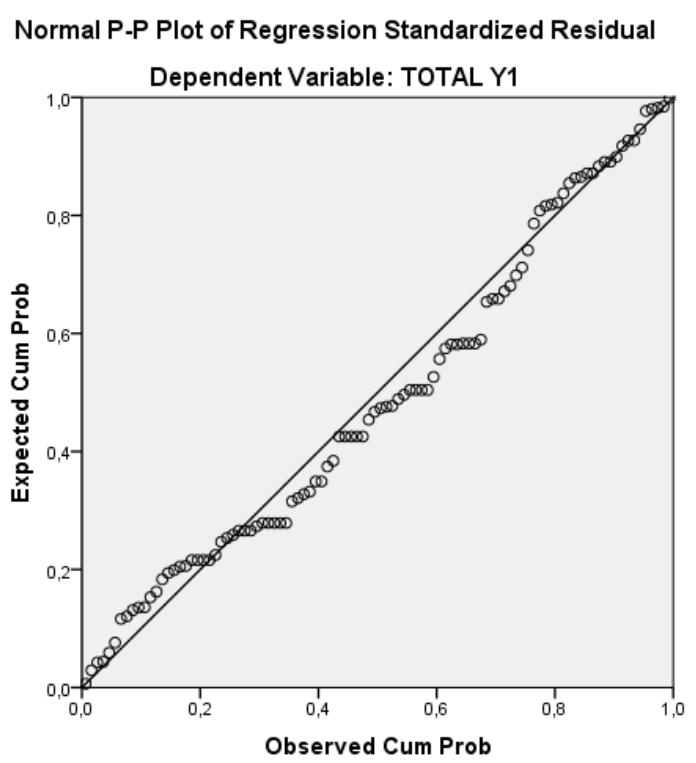

Sumber: Data Primer diolah, 2021

\section{Gambar 4. Uji Normalitas Sub Stuktural I}

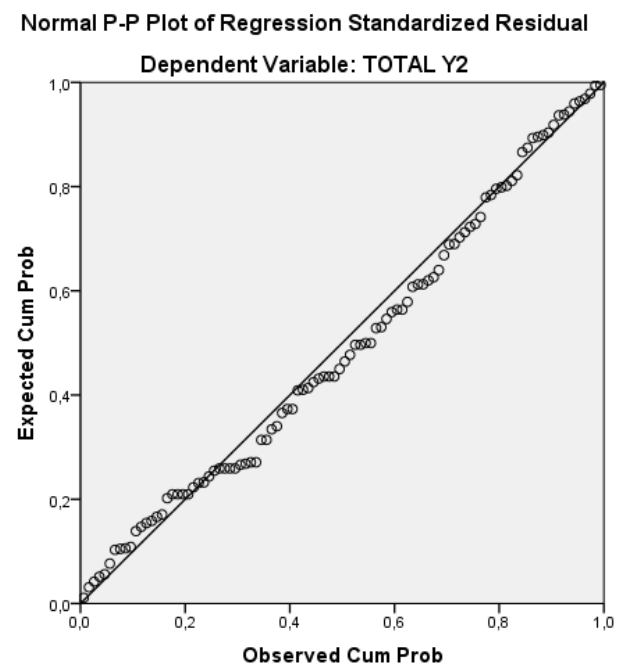

Sumber: Data Primer diolah, 2021

\section{Gambar 5. Uji Normalitas Sub Stuktural II}

Berdasarkan gambar 4 dan gambar 5 uji normalitas di atas terlihat bahwa data menyebar disekitar garis diagonal dan mengikuti arah garis diagonal. Maka model regresi memenuhi asumsi normalitas. 
Uji t

Tabel 7. Uji t Sub Struktural I

\begin{tabular}{|c|c|c|c|c|c|c|}
\hline \multirow{2}{*}{\multicolumn{2}{|c|}{ Model }} & \multicolumn{2}{|c|}{$\begin{array}{l}\text { Unstandardized } \\
\text { Coefficients }\end{array}$} & \multirow{2}{*}{$\begin{array}{c}\begin{array}{c}\text { Standardized } \\
\text { Coefficients }\end{array} \\
\text { Beta }\end{array}$} & \multirow[t]{2}{*}{$t$} & \multirow[t]{2}{*}{ Sig. } \\
\hline & & B & Std. Error & & & \\
\hline \multirow[t]{4}{*}{1} & (Constant) & 2,313 & 0,759 & & 3,048 & ,003 \\
\hline & CET & 0,168 & 0,041 & 0,411 & 4,139 & ,000 \\
\hline & Persepsi Nilai & 0,111 & 0,050 & 0,223 & 2,225 & ,028 \\
\hline & $\begin{array}{l}\text { Atribut } \\
\text { produk }\end{array}$ & 0,201 & 0,081 & 0,207 & 2,480 & ,015 \\
\hline
\end{tabular}

a. Dependent Variable: Sikap Konsumen

Sumber: Data Primer diolah, 2021

\section{a. Pengaruh Consumer Ethnocentrism Tendency terhadap Sikap Konsumen}

Consumer Ethnocentrism Tendency memiliki nilai sebesar 4,139>1,66071 dan signifikan sebesar $0,000<0,05$ sehingga di tolak dan di nyatakan diterima, maka dapat disimpulkan Consumer Ethnocentrism Tendency berpengaruh signifikan terhadap Sikap Konsumen. Besarnya pengaruh Consumer Ethnocentrism Tendency sebesar 0,411 atau 41,1\%.

b.Pengaruh Persepsi Nilai terhadap Sikap Konsumen

Persepsi Nilai memiliki nilai sebesar 2,225 >1,66071 dan signifikan sebesar 0,028<0,05 sehingga di tolak dan di nyatakan diterima, maka dapat disimpulkan Persepsi Nilai berpengaruh signifikan terhadap Sikap Konsumen. Besarnya pengaruh Persepsi Nilai sebesar 0,223 atau $22,3 \%$.

c. Pengaruh Atribut Produk terhadap Sikap Konsumen

Atribut Produk memiliki nilai sebesar 2,480>1,66071 dan signifikan sebesar 0,015 < 0,05 sehingga di tolak dan di nyatakan diterima, maka dapat disimpulkan Atribut Produk berpengaruh signifikan terhadap Sikap Konsumen. Besarnya pengaruh Atribut Produk sebesar 0, 207atau 20,7\%.

Tabel 8. Uji t Sub Struktural II

\begin{tabular}{|c|c|c|c|c|c|c|}
\hline & \multirow[t]{2}{*}{ Model } & \multicolumn{2}{|c|}{$\begin{array}{l}\text { Unstandardized } \\
\text { Coefficients }\end{array}$} & \multirow{2}{*}{$\begin{array}{c}\begin{array}{c}\text { Standardized } \\
\text { Coefficients }\end{array} \\
\text { Beta }\end{array}$} & \multirow[t]{2}{*}{$\mathbf{t}$} & \multirow[t]{2}{*}{ Sig. } \\
\hline & & B & Std. Error & & & \\
\hline \multirow[t]{5}{*}{1} & (Constant) & 4,613 & 1,009 & & 4,572 & 0,000 \\
\hline & CET & 0,173 & 0,056 & 0,355 & 3,092 & 0,003 \\
\hline & Persepsi Nilai & 0,112 & 0,065 & 0,189 & 1,729 & 0,087 \\
\hline & Atribut produk & 0,134 & 0,106 & 0,116 & 1,264 & 0,209 \\
\hline & Sikap Konsumen & 0,152 & 0,130 & 0,128 & 1,177 & 0,242 \\
\hline
\end{tabular}

a. Pengaruh Sikap Konsumen terhadap Niat Beli 
Sikap Konsumen memiliki nilai sebesar 1,177<1.66088 dan signifikan sebesar $0,242>0.05$ sehingga di terima dan di nyatakan ditolak, maka dapat disimpulkan bahwa sikap konsumen tidak berpengaruh signifikan terhadap niat beli. Besarnya pengaruh sikap konsumensebesar 0,128.

b. Pengaruh Consumer Ethnocentrism Tendency terhadap Niat Beli

Consumer Ethnocentrism Tendency memiliki nilai sebesar 3,092 >1,66088 dan signifikan sebesar 0,003<0,05 sehingga di tolak dan di nyatakan diterima, maka dapat disimpulkan Consumer Ethnocentrism Tendency berpengaruh signifikan terhadap Niat Beli. Besarnya pengaruh Consumer Ethnocentrism Tendency sebesar0,355.

c.Pengaruh Persepsi Nilai terhadap Niat Beli

Persepsi Nilai memiliki nilai sebesar 1,729>1,66088 dan signifikan sebesar 0,087 > 0, 05 sehingga di terima dan di nyatakan ditolak, maka dapat disimpulkan Persepsi Nilai tidak berpengaruh signifikan terhadap Niat Beli. Besarnya pengaruh persepsi nilai sebesar 0,189.

d. Pengaruh Atribut Produk terhadap Niat Beli

Atribut Produk memiliki nilai sebesar 1,264<1.66088 dan signifikan sebesar 0,209 > 0.05 sehingga di terima dan di nyatakan ditolak, maka dapat disimpulkan Atribut Produk tidak berpengaruh signifikan terhadap niat beli. Besarnya pengaruh Atribut Produk sebesar 0,116

\section{Analisis Jalur}

Tabel 9. Perhitungan Pengaruh

\begin{tabular}{cccc}
\hline No & Pengaruh Langsung & Pengaruh Tidak langsung & Pengaruh total \\
\hline 1 & $X_{1} \rightarrow Y_{1}=0,411$ & $X_{1} \rightarrow Y_{1} \rightarrow Y_{2}=0,053$ & $X_{1} \rightarrow Y_{1} \rightarrow Y_{2}=0,408$ \\
2 & $X_{2} \rightarrow Y_{1}=0,223$ & $X_{2} \rightarrow Y_{1} \rightarrow Y_{2}=0,029$ & $X_{2} \rightarrow Y_{1} \rightarrow Y_{2}=0,218$ \\
3 & $X_{3} \rightarrow Y_{1}=0,207$ & $X_{3} \rightarrow Y_{1} \rightarrow Y_{2}=0,026$ & $X_{3} \rightarrow Y_{1} \rightarrow Y_{2}=0,142$ \\
4 & $X_{1} \rightarrow Y_{2}=0,355$ & & $X_{1} \rightarrow Y_{2}=0,355$ \\
5 & $X_{2} \rightarrow Y_{2}=0,189$ & & $X_{2} \rightarrow Y_{2}=0,189$ \\
6 & $X_{3} \rightarrow Y_{2}=0,116$ & $X_{3} \rightarrow Y_{2}=0,116$ \\
7 & $Y_{1} \rightarrow Y_{2}=0,128$ & $Y_{1} \rightarrow Y_{2}=0,128$ \\
\hline \multicolumn{3}{c}{ Jumlah Pengaruh Total } & 1,556 \\
\hline
\end{tabular}

Sumber: Data Primer diolah, 2021 


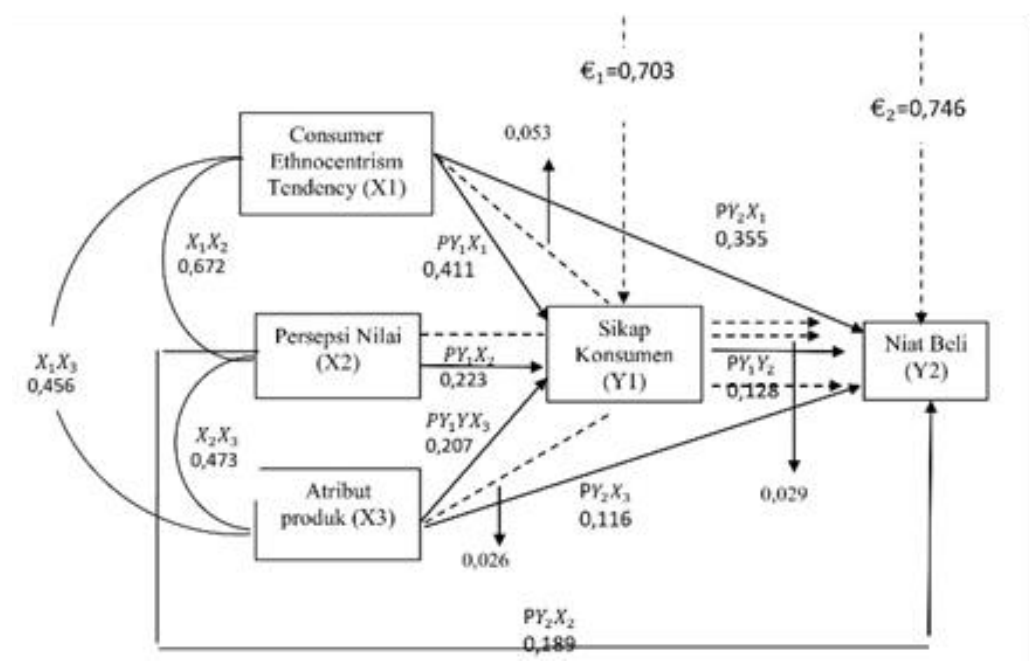

Sumber: Data Primer diolah, 2021

Gambar 6. Diagram Jalur

Berdasarkan gambar diagram analisis jalur di atas dapat dijelaskan bahwa variabel Consumer Ethnocentrism Tendency (CET) berpengaruh sebesar 0,411 terhadap sikap konsumen, variabel persepsi nilai berpengaruh sebesar 0,223 terhadap sikap konsumen, variabel atribut produk berpengaruh sebesar 0,207 terhadap sikap konsumen, variabel Consumer Ethnocentrism Tendency (CET) berpengaruh sebesar 0,355 terhadap niat beli, variabel persepsi nilai berpengaruh sebesar 0,189 terhadap niat beli. variabel atribut produkberpengaruh sebesar 0,116 terhadap niat beli, variabel sikap konsumenberpengaruh sebesar 0,128 terhadap niat beli. Korelasi antara Consumer Ethnocentrism Tendency (CET)dan atribut produkadalah 0,456.Korelasi antara Consumer Ethnocentrism Tendency (CET) dan persepsi nilaiadalah 0,672.Korelasi antara persepsi nilai dan atribut produkadalah 0,473.

\section{Uji Sobel}

Uji sobel dilakukan dengan cara menguji kekuatan pengaruh tidak langsung variabel independen $(X)$ dengan variabel dependen $(Y)$ lewat variabel intervening $(M)$ (Ghozali, 2013: 248-249). Sobel test dalam penelitian ini dihitung menggunakan kalkulator sobel-test yang diakses melalui website http:/ / quantpsy.org/sobel/sobel.htm:

Tabel. 10 Uji Sobel Sub Struktural I

\begin{tabular}{clc}
\hline $\begin{array}{c}\text { Test } \\
\text { Statistic }\end{array}$ & $\begin{array}{l}\text { Standard } \\
\text { Error }\end{array}$ & $p$-Value \\
\hline 1,12435211 & 0.02271175 & 0.26086368 \\
\hline
\end{tabular}

Sumber: Data Primer diolah, 2021

Berdasarkan table 10, menunjukan test statistic $<\mathrm{t}$ tabel yaitu 1,124 $<1,985$ dan $\mathrm{p}$-value $>\mathrm{a}$ yaitu 0,260 >0,05. Maka dapat disimpulkan bahwa sikap konsumen tidak dapat memediasi antara variabel CET dengan variabel niat beli. 
Tabel 11. Uji Sobel Sub Struktural II

\begin{tabular}{ccc}
\hline $\begin{array}{l}\text { Test } \\
\text { Statistic }\end{array}$ & $\begin{array}{l}\text { Standar } \\
\text { d Error }\end{array}$ & $\begin{array}{l}p \text { - } \\
\text { Value }\end{array}$ \\
\hline 1,03451806 & 0.01630904 & 0.30089404 \\
\hline
\end{tabular}

Sumber: Data Primer diolah, 2021

Berdasarkan tabel 11, menunjukan test statistic $<\mathrm{t}$ tabel yaitu 1,034 $<1,985$ dan $\mathrm{p}$-value $>\mathrm{a}$ yaitu 0,300 >0,05. Maka dapat disimpulkan bahwa sikap konsumen tidak dapat memediasi antara variabel CET dengan variabel niat beli.

Tabel 12. Uji Sobel Sub Struktural III

\begin{tabular}{clc}
\hline $\begin{array}{l}\text { Test } \\
\text { Statistic }\end{array}$ & $\begin{array}{l}\text { Standard } \\
\text { Error }\end{array}$ & $p$-Value \\
\hline 1,05769956 & 0,02888533 & 0,29019244 \\
\hline
\end{tabular}

Sumber: Data Primer diolah, 2021

Berdasarkan tabel 12, menunjukan test statistic $<\mathrm{t}$ tabel yaitu 1,057 <1,985 dan p-value $>\mathrm{a}$ yaitu 0,290 > 0,05. Maka dapat disimpulkan bahwa sikap konsumen tidak dapat memediasi antara variabel atribut produk dengan variabel niat beli.

\section{Pembahasan}

\section{Pengaruh Consumer Ethnocentrism Tendency (CET) terhadap Sikap Konsumen}

Pengujian hipotesis pertama dilakukan untuk mengetahui pengaruh Consumer Ethnocentrism Tendency (CET) terhadap Sikap Konsumen. Hasil penelitian menunjukkan nilai $\mathrm{t}$ hitung sebesar 4,139 > ttabel1.66071 dengan tingkat signifikansi sebesar 0,000 < 0,05 sehingga H0 ditolak dan H1 dinyatakan diterima. Oleh karena itu, dapat disimpulkan bahwa Consumer Ethnocentrism Tendency (CET) berpengaruh signifikan terhadap Sikap Konsumen pada produk batik Kebumen. Hal tersebut menjelaskan bahwa semakin seseorang tersebut memiliki kecenderungan jiwa yang ehnocentrism terhadap batik Kebumen maka akan memunculkan adanya sikap konsumen yang positif pada produk batik Kebumen, selain itu juga berdasarkan jawaban responden yang diperoleh dari hasil kuesioner menunjukan bahwa sebagain besar responden memiliki penilaian yang tinggi terhadap variabel CET. Hasil positif berkaitan dengan pertanyaan dalam kuesioner yang menyatakan adanya bahwa orang kebumen harus memiliki batik kebumen sebagai bukti cinta terhadap produk lokal, sehingga ketika seorang konsumen tersebut memiliki cinta terhadap produk lokal maka akan memunculkana adanya sikap konsumen yang tinggi. Hasil penelitian ini sejalan dengan penelitian yang dilkakukan oleh novita (2017) yang mengatakan bahwa ethnocentrism konsumen berpengaruh positif dan signifikan terhadap sikap konsumen terhadap produk lokal.

\section{Pengaruh Persepsi Nilai terhadap Sikap Konsumen}

Pengujian hipotes kedua dilakuakan untuk mengetahui pengaruh persepsi nilai terhadap sikap konsumen. Persepsi Nilai memiliki nilai sebesar 2,225>1,66071 dan signifikan sebesar $0,028<0,05$ sehingga di tolak dan di nyatakan diterima, maka dapat disimpulkan persepsi nilai berpengaruh signifikan terhadap sikap konsumen pada produk batik Kebumen. Hal 
tersebut menjelaskan bahwa ketika konsumen memiliki persepsi nilai yang baik terhadap batik Kebumen maka akan memunculkan adanya sikap konsumen yang positif terhadap produk batik Kebumen tersebut, dimana ketika konsumen dalam memilih suatu produk, mereka merasakan kontribusi atau keunikan sendiri yang mennetukan sikap mereka pada produk tersebut. Terlihat bahwa persepsi nilai memiliki pengaruh yang sama terhadap sikap baik pada barang, salah satunya produk batik Kebumen. Hasil penelitian ini sejalan dengan penelitian yang dilakukan oleh Carrayanta (2020) mengatakan bahwa persepsi nilai berpengaruh positif terhadap sikap konsumen.

\section{Pengaruh Atribut Produk terhadap Sikap Konsumen}

Pengujian hipotesis ketiga dilakukan untuk mengetahui pengaruh atribut produk terhadap sikap konsumen Atribut Produk memiliki nilai sebesar 2,480 >1,66071 dan signifikan sebesar 0,015<0,05 sehingga di tolak dan di nyatakan diterima, maka dapat disimpulkan Atribut Produk berpengaruh signifikan terhadap Sikap Konsumen. Hal tersebut sejalan dengan penelitian Devis dan kolin (2018) mengemukakan adanya hasil penelitian menunjukkan bahwa terdapat pengaruh atribut produk $(\mathrm{x})$ terhadap sikap konsumen $(\mathrm{z})$ mahasiswa pengguna produk sepatu vans di kawasan babarsari. Selain itu juga bahwa adanya atribut pada sebuah produk memiliki peran yang penting, karena atribut produk menjadi salah satu faktor yang menjadi pertimbangan konsumen dalam memilih suatu produk tersebut dan setiap produk pasti memiliki karakteristik fisik yang membedakan dengan produk pesaing yang di sebut atribut produk.

\section{Pengaruh Sikap Konsumen Terhadap Niat Beli}

Pengujian hipotesis keempat dilakukan untuk mengetahui pengaruh sikap konsumen terhadap niat beli. Sikap Konsumen memiliki nilai sebesar 1,177 <1,66088 dan signifikan sebesar 0,242>0,05 sehingga di terima dan di nyatakan ditolak, maka dapat disimpulkan bahwa sikap konsumen tidak berpengaruh signifikan terhadap niat beli. Artinya sikap masyarakat kebumen tidak mempengaruhi niat konsumen untuk membeli batik Kebumen. Karena kebanyakan masyarakat kebumen dalam membeli batik tidak melihat itu batik produksi kebumen atau bukan yang terpenting motif tersebut batik.

Berdasarkan jawaban responden yang diperoleh dari hasil kuisioner menunjukkan bahwa beberapa responden memberikan penilaian yang rendah terhadap sikap konsumen. Hal tersebut berdasarkan indikator sikap konsumen dimana beberapa responden pada Hasil penelitian ini sejalan dengan aragumen bahwa sikap konsumen terhadap produk batik Kebumen memiliki nilai yang rendah, maka niat beli pada produk batik juga rendah. Hal tersebut sejalan dengan penelitian sukardi dan iksan (2020) yang mengatakan bahwa sikap tidak berpengaruh secara signifikan terhadap niat beli.

\section{Pengaruh Consumer Ethnocentrism Tendency terhadap Niat Beli}

Pengujian hipotesis kelima dilakukan untuk mengetahui pengaruh consumer ethnocentrism tendency terhadap niat beli. Consumer Ethnocentrism Tendency memiliki nilai sebesar 3,092 >1.66088 dan signifikan sebesar 0,003<0.05 sehingga di tolak dan di nyatakan diterima, maka dapat disimpulkan Consumer Ethnocentrism Tendency berpengaruh signifikan terhadap Niat Beli. Artinya ketika masyarakat Kebumen memiliki kecenderungan sikap yang etnocentrism maka akan meningkatkan adnaya niat beli pada produk batik Kebumen karena, konsumen yang memiliki sikap ethnocentrism yang tinggi akan merasa rugi jika membeli produk yang bukan produk domestik, tentu hal tersebut di dukung adanya penelitian Ni Putu Anggun Udayani, Made Wardana, IG.A.K. Giantari (2018) yang mengemukakan etnocentrisme konsumen berpengaruh signifikan positif terhadap niat beli. 


\section{Pengaruh Persepsi Nilai terhadap Niat Beli}

Pengujian hipotesis keenam dilakukan untuk mengetahui Persepsi Nilai terhadap niat beli. Persepsi nilai memiliki nilai sebesar 1,729>1.66088 dan signifikan sebesar 0,087 >0,05 sehingga di terima dan di nyatakan ditolak, maka dapat disimpulkan Persepsi Nilai tidak berpengaruh signifikan terhadap Niat Beli. Dalam penelitian ini variabel persepsi nilai di ukur 5 indikator.

Berdasarkan jawaban responden indikator kesesuain harga dengan produk memiliki jawaban yang mendominasi. Artinya masyarakat Kebumen dalam membeli batik Kebumen tidak terlalu mempertimbangkan harga dengan kesesuain produk yang di berikan. Namun hal tersebut tidak sejalan dengan penelitian dari Chen., et al (2018) yang berjudul "Purchase intention in social commerce: An empirical examination of perceived value and social awareness" menemukan bahwa persepsi nilai berpengaruh signifikan positif terhadap niat beli. Jika konsumen merasa produk yang dinilai memiliki nilai yang tinggi, konsumen akan membeli produk tersebut.

\section{Pengaruh Atribut Produk Terhadap Niat Beli}

Pengujian hipotesis ketujuh dilakukan untuk mengetahui Atribut Produk Terhadap Niat Beli. Atribut Produk memiliki nilai sebesar 1,264 <1,66088 dan signifikan sebesar 0,209 > 0,05 sehingga di terima dan di nyatakan ditolak, maka dapat disimpulkan atribut Produk tidak berpengaruh signifikan terhadap niat beli. Artinya adanya atribut produk yang melekat pada batik Kebumen tidak menjadi pertimbangan yang penuh untuk memiliki niat beli batik Kebumen. Hal tersebut menjelaskan bahwa atribut produk tidak mempengaruhi niat beli konsumen terhadap produk batik Kebumen. Hasil penelitian ini tidak sejalan dengan teori yang dikemukakan Holak (1990) dalam Ho dan Wu (2011) yang menyatakan niat membeli sebagian besar dipengaruhi oleh atribut produk yang dirasakan dan karakter konsumen, tetapi hal ini sejalan dengan penelitian Suki (2013) yang menyatakan bahwa product attributes tidak terbukti berpengaruh terhadap purchase intention.

Pengaruh Consumer Ethnocentrism Tendency terhadap Niat Beli melalui Sikap Konsumen.

Berdasarkan hasil uji statistik yang sebelumnya telah dilakukan maka dapat diketahui bahwa Consumer Ethnocentrism Tendency terhadap Niat Beli melalui Sikap Konsumen memiliki pengaruh sebesar 0,053 atau 5,3\%.

\section{Pengaruh persepsi nilai terhadap Niat Beli melalui Sikap Konsumen.}

Berdasarkan hasil uji statistik yang sebelumnya telah dilakukan maka dapat diketahui bahwa persepsi nilai terhadap Niat Beli melalui Sikap Konsumen memiliki pengaruh sebesar 0,029 atau 2,9\%. Hasil penelitian ini sesuai dengan teori yang dikemukakan oleh (Engel, 1995:141) dalam model perilaku konsumen menurut Engel, et al dapat diketahui bahwa jika niat seseorang didahului oleh munculnya sikap.

\section{Pengaruh Atribut Produk terhadap Niat Beli melalui Sikap Konsumen}

Berdasarkan hasil uji statistik yang sebelumnya telah dilakukan maka dapat diketahui bahwa persepsi nilai terhadap Niat Beli melalui Sikap Konsumen memiliki pengaruh sebesar 0,026 atau 2,6\%. Hal ini menunjukan bahwa jika batik kebumen memiliki berbagai atribut produk yang menarik seperti dari segi kemasan, jenis merek, pelayanan maka dapat meningkatkan niat beli konsumen penelitian yang di lakukan Raden Sheila Arismarcella (2017). 


\section{Penutup}

\section{Simpulan}

Berdasarkan hasil pembahasan analisis data maka dapat diperoleh kesimpulan sebagai berikut:

1. Hasil penelitian menunjukan bahwa Consumer Ethnocentrism Tendency berpengaruh signifikan terhadap Sikap Konsumen pada produk batik Kebumen.

2. Hasil penelitian menunjukan bahwa Persepsi Nilai berpengaruh signifikan terhadap Sikap Konsumen pada produk batik Kebumen .

3. Hasil penelitian menunjukan bahwa atribut produk berpengaruh signifikan terhadap sikap konsumen.

4. Hasil penelitian menunjukan bahwa sikap konsumen tidak berpengaruh signifikan terhadap niat beli. Artinya sikap masyarakat kebumen tidak mempengaruhi niat konsumen untuk membeli batik Kebumen.

5. Hasil penelitian menunjukan bahwa Consumer Ethnocentrism Tendency berpengaruh signifikan terhadap Niat Beli. Artinya ketika masyarakat Kebumen memiliki kecenderungan sikap yang etnocentrism maka akan meningkatkan adnaya niat beli pada produk batik Kebumen karena, konsumen yang memiliki sikap ethnocentrism yang tinggi akan merasa rugi jika membeli produk yang bukan produk domestik.

6. Hasil penelitian menunjukan bahwa persepsi nilai tidak berpengaruh signifikan terhadap niat beli. Berdasarkan jawaban responden indikator kesesuain harga dengan produk memiliki jawaban yang mendominasi. Artinya masyarakat Kebumen dalam membeli batik Kebumen tidak terlalu mempertimbangkan harga dengan kesesuain produk yang di berikan.

7. Hasil penelitian menunjukan bahwa atribut produk tidak berpengaruh signifikan terhadap niat beli. Artinya adanya atribut produk yang melekat pada batik Kebumen tidak menjadi pertimbangan yang penuh untuk memiliki niat beli batik Kebumen.

8. Hasil penelitian menunujukan bahwa consumer ethnocentrism tendency, persepsi nilai dan atribut produk tidak dapat di mediasi oleh sikap konsumen terhadap niat beli pada produk batik Kebumen.

\section{Keterbatasan}

1. Berdasarkan penelitian yang telah dilakukan, maka penelitian ini menjelaskan bahwa substruktural I sebanyak 48,9\%.Artinya sebesar 48,9\% variabel Sikap Konsumen pada produk batik Kebumen dapat dijelaskan oleh variabel persepsi nilai, CET, dan atribut produk. Kemudian untuk substruktural II sebanyak $42 \%$.Artinya sebesar $42 \%$ variabel niat beli pada produk batik Kebumen dapat dijelaskan oleh variabel CET, Atribut produk, persepsi nilai, dan sikap konsumen.

2. Penelitan selanjutnya disarankan untuk meneliti variabel lain pada penelitian yang serupa seperti WOM, product quality, dan brand image agar dapat memperkaya kajian penelitian yang serupa, serta agar pembaca dapat mengetahui variabel lainnya yang dapat mempengaruhi niat beli pada produk batik Kebumen.

3. Keterbatasan adanya responen pada konsumen batik Kebumen yang kurang tepat, dimana umur responden batik seharusnya pada umur $>34$ tahun dengan anggapan memiliki pendapatan per bulan $>$ Rp.3.000.000. Namun pada penelitian ini sample responden umur 17-22 tahun dengan pendapatan rendah yaitu $<$ Rp.1.000.000. 


\section{Referensi}

Amri, S., \& Prihandono, D. (2019). Influence Lifestyle, Consumer Ethnocentrism, Product Quality on Purchase Decision Through Purchase Intention. Management Analysis Journal, 8(1), 25-38.

Anggasari, P., Yuliati, L. N., \& Retnaningsih, R. (2013). Pengaruh Ethnosentrisme Terhadap Sikap, Preferensi dan Perilaku Pembelian Buah Lokal dan Impor. Jurnal Manajemen $\mathcal{E}$ Agribisnis, 10(2), 128-136.

Arismarcella, R., S. 2017. Analisis Pengaruh Atribut produk terhadap niat beli tas roopack di kota bandung. Skripsi. Universitas Katolik Parahyangan.

Aybeniz Akdeniz, A. R. (2013). Effect Of Perceived Values On The Brand Preference And The Purchase Intention. European Scientific Journal, 8(17).

Carrayanta, V. (2020). Analisis pengaruh service quality dan experience quality terhadap customer loyalty melalui perceived value dan attitude pada pelanggan Djournal coffee di Surabaya. Doctoral Dissertation. Universitas Pelita Harapan.

Diwangkoro, L. (2018). Pengaruh Kesadaran Merek, Word Of Mouth, dan Persepsi Risiko Terhadap Niat Beli Box Merek Givi di Surabaya. Doctoral Dissertation. STIE Perbanas Surabaya.

Dwi, K, I. R. M. A. (2015). Pengaruh pengetahuan produk terhadap niat beli dengan sikap sebagai variabel intervening. Jurnal Ilmu Manajemen (JIM), 2(4).

Fibrianti, L., Fauzi, A., \& Arifin, Z. (2013). PENGARUH ATRIBUT PRODUK TERHADAP SIKAP (Survei pada Ibu Rumah Tangga Konsumen Pewangi dan Pelembut Pakaian Merek "Molto Sekali Bilas" di Desa Bandar Kidul Kecamatan Mojoroto Kota Kediri). Jurnal Administrasi Bisnis, 2(1), 84-92.

Firmansya A. (2017). Analisis Pengaruh Consumer Animosity Dan Consumer Ethnocentrism Terhadap Purchase Intention. Skripsi. Manajanemen. Universitas Muhammadiyah.

Ghozali, I. (2003). Aplikasi Analisis Multivariate dengan Program SPSS. Edisi Kedua. Semarang: Badan Penerbit Universitas Diponegoro.

Kurnianto M. (2015). Pengaruh Etnocentrismme Konsumen, Persepsi Harga Dan Kemenarikan Atribut Terhadap Sikap Produk Dan Implikasinya Terhadap Keputusan Pembelian. Skripsi.Universitas Diponegoro.

Larasati, A., Hati, S. R. H., \& Safira, A. (2018). Religiusitas dan Pengetahuan Terhadap Sikap dan Intensi Konsumen Muslim untuk Membeli Produk Kosmetik Halal. Esensi: Jurnal Bisnis Dan Manajemen, 8(2), 105-114.

Miauw, K. Y. H. (2016). Motivasi Konsumen Dan Sikap Konsumen Terhadap Keputusan Pembelian Di Wild. Jurnal Manajemen Dan Start-Up Bisnis, 1(5), 567-575.

Murti, W., \& Fernandez, D. (2020). Analisis Gaya Hidup Dan Etnocentrismme Konsumen Terhadap Persepri Kualitas Serta Implikasinya Terhadap Niat Beli Konsumen (Studi Kasus Pada Pengguna Smartphone Smartfren Andromas Pengunjung Itc Roxy Mas Jakarta). Jurnal Manajemen FE-UB, 7(1), 141-160. 
Novandari, W., Setyawati, S. M., \& Wulandari, S. Z. (2011). Analisis kinerja produk UKM batik Banyumas dengan menggunakan metode Importance Performance Analysis (IPA) dan potential gain of customer value's (PGCV) index. Jurnal Bisnis dan Ekonomi, 18(2).

Nusawie, H. N., \& Rusmawati, D. (2018). Hubungan Antar Customer Value Dengan Intensi Pembelian Batik Semarang Pada Anggota Dharma Wanita Persatuan Universitas Diponegoro. Jurnal Empati, 7(3), 174-178.

Permatasari, M. I., \& Soesanto, H. (2015). Analisis Consumer Ethnosentrism Dan Perceived Value Terhadap Minat Beli Konsumen Dengan Brand Image Sebagai Mediator. Diponegoro Journal Of Management, 4(3), 1-9.

Putra, I. M. Y. A., \& Rahyuda, K. (2018). Peran Perceived Value Memediasi Hubungan Kualitas Pelayanan Dengan Kepuasan Konsumen. E-Jurnal Manajemen, 7(5), 2793-2822.

Qadry, R. A. (2019, September). The Impact of Product Attributes, Personality, and Word of Mouth on Purchase Intention Product of Gift of Typical Food of West Sumatera. In Third Padang International Conference On Economics Education, Economics, Business and Management, Accounting and Entrepreneurship (PICEEBA 2019) (pp. 391-397). Atlantis Press.

Rahayu, S. (2018). Pengaruh Atribut Produk Terhadap Sikap Konsumen Surat Kabar Sindo. Jurnal Semarak, 1(2), 95-104.

Rahmi, S., \& Amalia, R. (2018). Pengaruh E-WoM Terhadap Citra Perusahaan dan Dampaknya terhadap Niat Beli Konsumen Pada Situs Online Shopee. Id. Jurnal Ilmiah Mahasiswa Ekonomi Manajemen, 3(2), 75-84.

Retnowati. (2011). Pengaruh Atribut Produk Batik Terhadap Keputusan Konsumen Membeli Produk Batik. Jurnal Ekonomi dan Bisnis, 9(1).

Riptiono, S., Anggraeni, A. I., Suroso, A., \& Azizah, S. N. (2020). Intention To Purchase Local Food Products Among Indonesian Young Consumers. Humanites \& Social Sciences Review, 8(4), 2395-6518.

Safitri, L., \& Riptiono, S. (2020). Pengaruh Self Image Congruence, Luxury Value Dan Product Attribute Terhadap Repurchase Intention Melalui Satisfaction Sebagai Variabel Intervening. Jurnal Ilmiah Mahasiswa Manajemen, Bisnis dan Akuntansi (JIMMBA), 2(4), 681-688.

Saidani, B., \& Ramadhan, D. R. (2013). Pengaruh iklan dan atribut produk terhadap keputusan pembelian smartphone samsung seri galaxy (survei pada pelanggan itc roxy mas). JRMSI-Jurnal Riset Manajemen Sains Indonesia, 4(1), 53-73.

Shierly, L., \& Sihombing, S. O. (2015). Pengaruh faktor internal dan eksternal terhadap sikap dan niat pembelian daring. EKUITAS (Jurnal Ekonomi dan Keuangan), 19(2), 192-216.

Sudarti, K. (2013). Peningkatan Minat Pembelian Merek Lokal Melalui Consumer Ethnocentrisme. VALUE ADDED | MAJALAH EKONOMI DAN BISNIS, 9(2). 
Sumaryati, M. M., \& Gregie, G. (2016). Analisis Atribut Produk Terhadap Perilaku Pembelian Konsumen Sepatu Merek Nike. Jurnal Manajemen, 13(1), 58-75.

Sunyoto, D. (2013). Teori, Kuesioner \& Analisis Data Untuk Pemasaran dan Perilaku Konsumen. Edisi 1. Yogyakarta. Graha Ilmu.

Tjiptono, F., \& Chandra, G. (2012). Pemasaran Global Konteks Offline E Online. Yogyakarta: UPP STIM YKPN.

Trifiyanto, K. (2018). Masa Depan Produk Lokal: Analisis Pengaruh Etnosentris Konsumen, Disain Kemasan dan Persepsi Labelisasi Halal Terhadap Minat Pembelian Produk Lokal. Fokus Bisnis: Media Pengkajian Manajemen dan Akuntansi, 17(2), 15-24.

Wiryantari, A. I. C., \& Sukawati, T. G. R. (2016). Peran Persepsi Nilai Dalam Memediasi Pengaruh Kredibilitas Celebrity Endorser Pada Niat Beli Produk Kosmetik Wardah. EJurnal Manajemen, 5(11). 